\title{
Groundwater recharge estimation studies in a khondalitic terrain of India
}

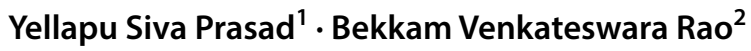

Received: 5 December 2017 / Accepted: 4 June 2018 / Published online: 19 June 2018

(c) The Author(s) 2018

\begin{abstract}
Agriculture is the main occupation in the Kandivalasa river sub-basin (KRSB) covered with khondalitic terrain of Eastern Ghats of India. The farmers are mainly depending on groundwater for irrigation in non-monsoon period in the study area; as such it is important to know how much rainfall recharge is occurring to the groundwater table. The groundwater recharge is assessed in the KRSB by collecting the pre- and post-monsoon groundwater levels at 42 observation wells and rainfall data covering the entire basin during the years 2013-2016. The groundwater recharge has been calculated using both water table fluctuation method and rainfall infiltration method. The study revealed in the basin that the per cent of rainfall converting to the groundwater recharge is $11.12,13.18,9.51$ and $12.80 \%$ for the years $2013,2014,2015$ and 2016, respectively. The study has also revealed that the heavy rainfall events with prolonged time lead to the rise in the groundwater levels, thereby increasing the groundwater recharge. It is also observed that the deeper the pre-monsoon groundwater level, the more the recharge in the basin.
\end{abstract}

Keywords Khondalites · Groundwater recharge $\cdot$ Pre-monsoon groundwater levels $\cdot$ Kandivalasa river sub-basin

\section{Introduction}

Agriculture is the main occupation in the study area, namely Kandivalasa river sub-basin (KRSB) of Eastern Ghats of India near Cheepurupally town of Vizianagaram district of Andhra Pradesh. The farmers are mainly depending on groundwater for irrigation in non-monsoon period. Hence, it is important to know how much rainfall recharge is occurring to the groundwater table (Wu et al. 1996; Shah 2005). Moreover, the groundwater recharge is a key component in any model of groundwater flow or contaminant transport (Zomlot et al. 2015; Cooper et al. 2015). One of the objectives of the study is to estimate the groundwater recharge in the basin during the years 2013-2016 for a sustainable

Yellapu Siva Prasad

sivaprasad.gw@gmail.com

Bekkam Venkateswara Rao

cwr_jntu@yahoo.com

1 Deltaic Regional Centre, National Institute of Hydrology, Kakinada, Andhra Pradesh, 533003, India

2 Centre for Water Resources, Institute of Science and Technology, Jawaharlal Nehru Technological University Hyderabad, Hyderabad 500085, India development of the groundwater resources. The influence of pre-monsoon groundwater levels over the groundwater recharge in the basin is also analysed and discussed.

Out of various methods for estimating the groundwater recharge, methods based on the groundwater levels are widely used (Sophocleous 1991; Crosbie et al. 2005; Healy 2010) due to the abundance of groundwater level data and the simplicity of the analysis of data to estimate the groundwater recharge (Bhuiyan et al. 2009). Healy and Cook (2002) stated that, out of physical-based techniques, water table fluctuation (WTF) method is based on recharge effect and is being widely used more than chemical-based techniques for estimating groundwater recharge in semi-arid regions. Nichols and Verry (2001), Delin et al. (2007) and Crosbie et al. (2005) described that the WTF method is based on the rise in groundwater levels due to groundwater recharge. Rainfall infiltration factor method (RIF) is also the indirect method for estimating the groundwater recharge (Bhuiyan et al. 2009; Jasrotia and Kumar 2014). Rainfall infiltration rate represents the infiltration factor values governed by infiltration capacity of the unsaturated zone. In the absence of site-specific values, the norms and guidelines developed by the Central Groundwater Board (CGWB) (GEC 1997) of India, based on measurements with similar hydrogeologic 
units can be used (Kumar and Srinivas 2012). Varni et al. (2013) applied the WTF method to characterize groundwater recharge in the Pampa Plain, Argentina. Thomas et al. (2009) estimated the groundwater recharge based on the Groundwater Estimation Committee (GEC) norms for a fractured basaltic aquifer in Central India. Ngounou et al. (2007) estimated the groundwater recharge from the rainfall infiltration method from the southern border of Lake Chad in Cameroon. The impact of changing rainfall intensities on groundwater recharge is carefully studied by Owor et al. (2009) in the Upper Nile Basin. The study showed that the magnitude of observed recharge events is better related to heavy rainfalls in the basin exceeding a threshold of $10 \mathrm{~mm} /$ day, than to that of all daily rainfall events. The soil-moisture balance study indicated that the groundwater recharge is more dependent on the continuous heavy rainfall of the total annual volume of rainfall (Sethi et al. 2009).

\section{The study area}

Kandivalasa river sub-basin (KRSB) (Fig. 1) near Cheepurupally town of Vizianagaram district of Andhra Pradesh, India, covered with a typical khondalitic suite of rocks and situated between east longitudes of $83^{\circ} 32^{\prime} 15^{\prime \prime}-83^{\circ} 39^{\prime} 10^{\prime \prime}$ and north latitudes of $18^{\circ} 9^{\prime} 15^{\prime \prime}-18^{\circ} 19^{\prime} 54^{\prime \prime}$ having an areal extent of $121 \mathrm{~km}^{2}$ is selected for this study. It forms a part of Survey of India toposheet nos. E44L11 and E44L12. In general, the area is covered by a thick soil cover (1-4 m) followed by weathered and fractured khondalitic formation underlain by basement of granite gneiss. Quite often the highly weathered khondalite is acting as aquitard atop the main khondalitic fractured aquifer (Venkateswara Rao and Ramadurgaiah 2002). The area is highly disturbed due to folding, faulting and fracturing with isolated hills covered by khondalitic rocks on the top and lateritic soils on the sides (Fig. 2). Occasionally, quartz veins are seen exposed to surface often serving as guide to locate high yielding wells. The topography of the area is undulating. At all locations between hills, there is a high slope in the foot hill region and a gentle slope towards the valley (Fig. 3). Frequently, small

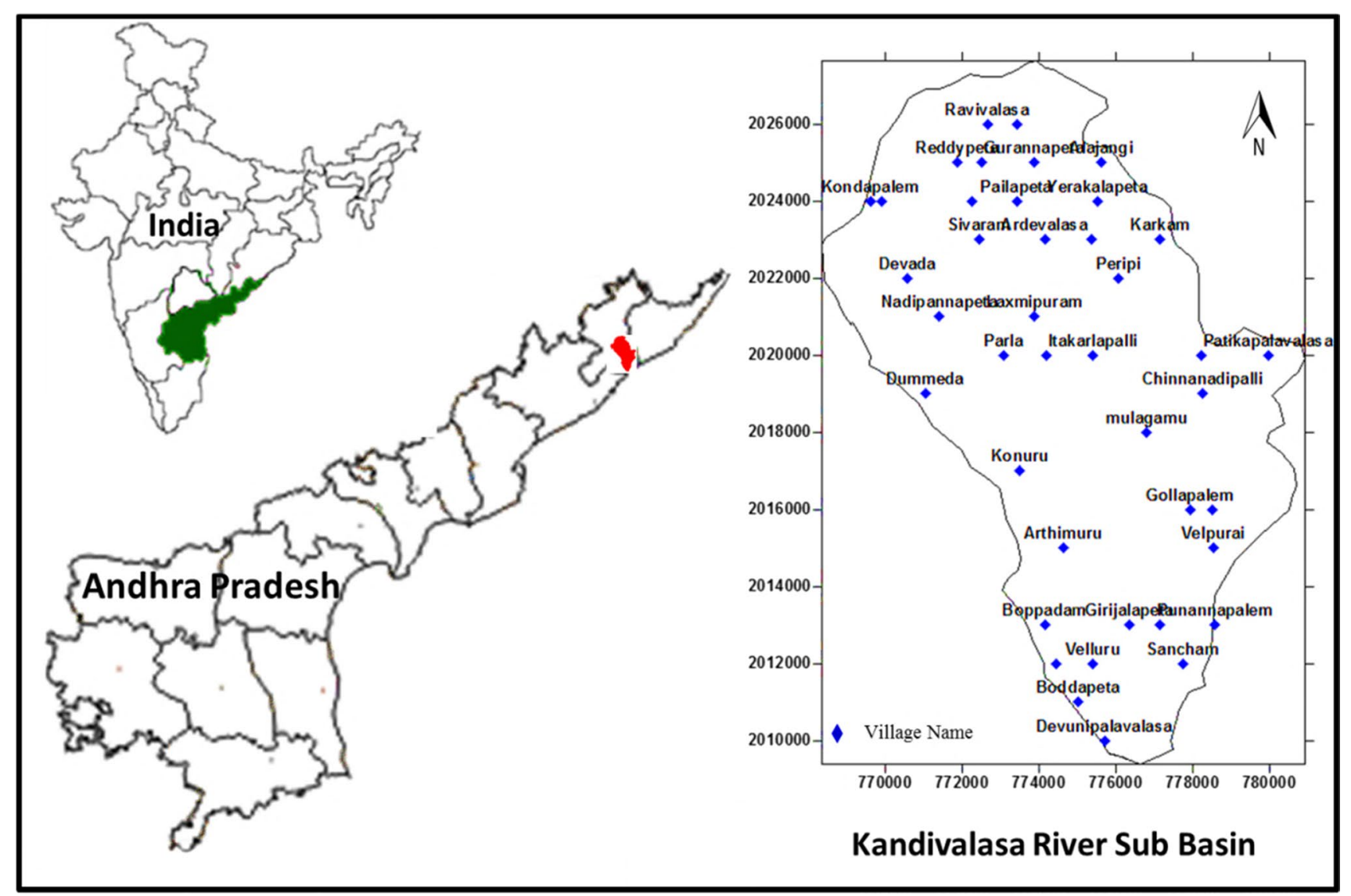

Fig. 1 Location of Kandivalasa river sub-basin in the Vizianagaram district, Andhra Pradesh, India 


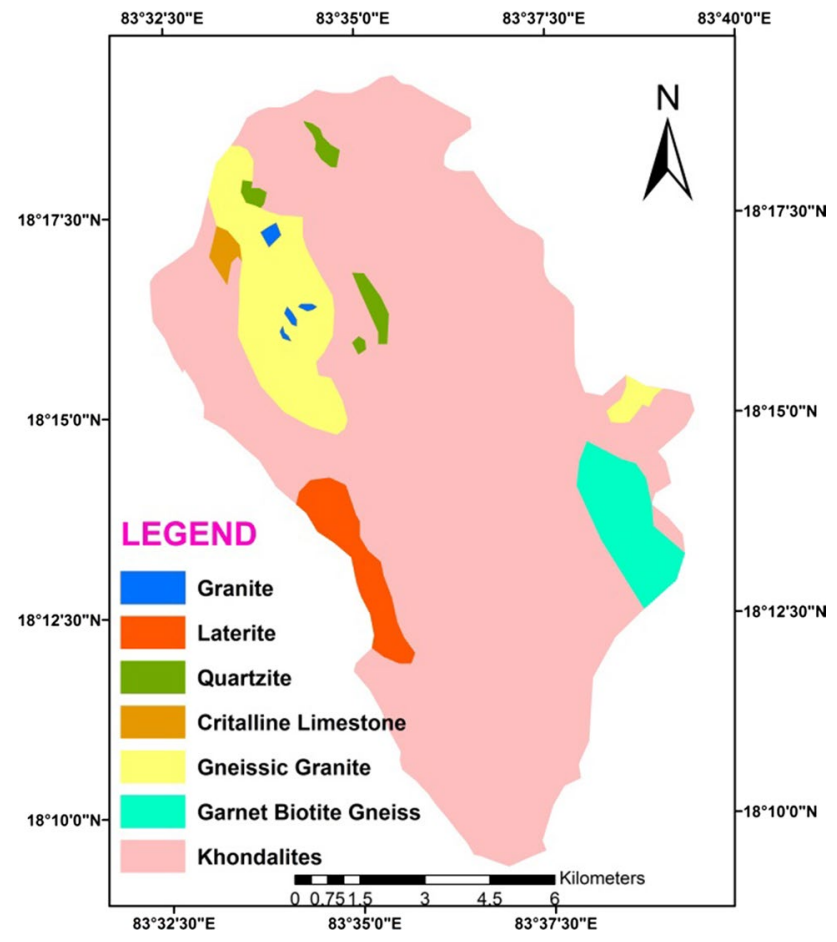

Fig. 2 Geology map of the Kandivalasa river sub-basin (Siva Prasad and Venkateswara Rao 2018)

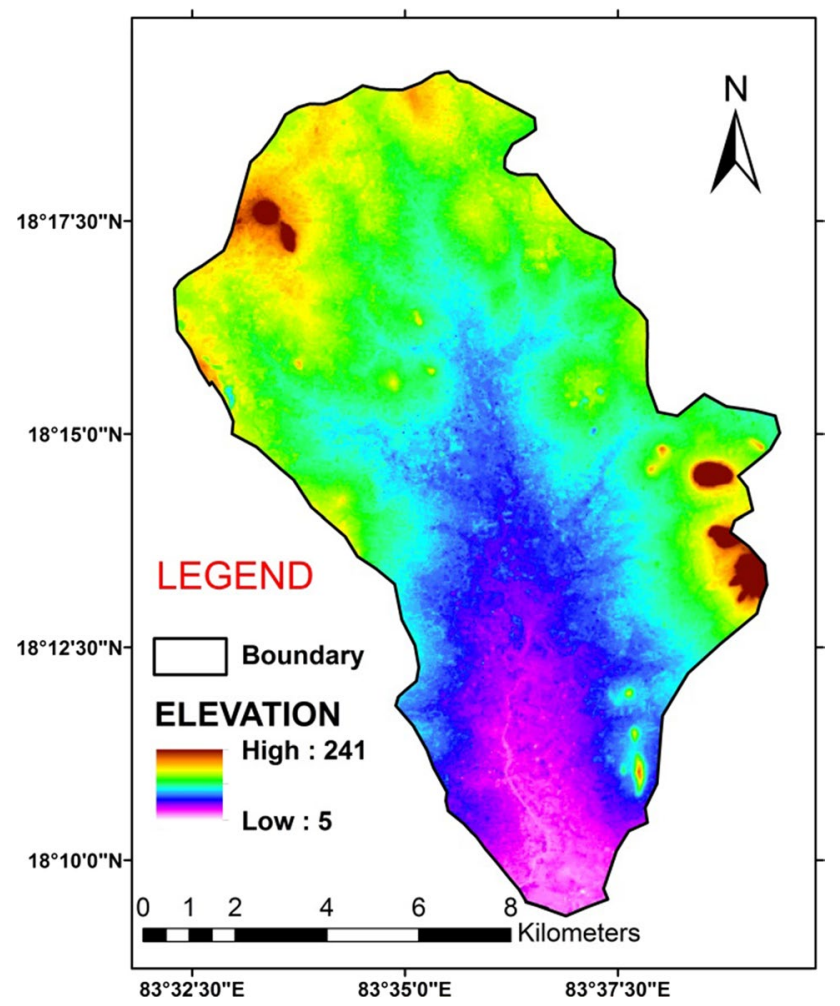

Fig. 3 Digital elevation map of the Kandivalasa river sub-basin plateaus are also observed. The average annual rainfall is around $1000 \mathrm{~mm}$. Groundwater occurs under semi-confined conditions in the weathered portion of the khondalite. But the fact that the rise of water table in the bore well after penetrating the fractured environment and drying up of nearby open wells after pumpage of bore wells, demonstrates that the weathered and fractured environment are hydrologically connected and the fractured environment is under semiconfining conditions (Venkateswara Rao and Briz-Kishore 1991).

\section{Materials and methods}

In the present study, groundwater recharge is assessed in KRSB covered with khondalitic terrain near Cheepurupally mandal, Vizianagaram district of Andhra Pradesh, India, by collecting the pre- and post-monsoon groundwater levels at 41 observation wells and rainfall data of five mandals (an administrative unit of the district) covering the entire basin for the years 2013, 2014, 2015 and 2016. In this terrain, generally groundwater is available only in weathered and fractured zones under unconfined to semi-confined conditions (Venkateswara Rao and Briz-Kishore 1991). The groundwater recharge has been calculated using both RIF method and WTF method as per methodology recommended by Groundwater Estimation Committee (GEC 1997). The contour maps of groundwater fluctuations and rainfall data are prepared from the Surfer software (Jan et al. 2007). By using the recharge values obtained in Million Cubic Metre (MCM) from the both WTF method and RIF method, the per cent of rainfall converted into groundwater recharge for the years 2013, 2014, 2015 and 2016 is calculated with the help of the set of criteria adopted from the GEC norms. By using rainfall data during the study period, the influence of pre-monsoon groundwater levels over the rainfall recharge to groundwater (Venkateswara Rao et al. 2007) in the basin is also analysed and discussed. The theoretical background for estimating the groundwater recharge from the GEC norms is described below.

\section{Estimation of groundwater recharge from WTF method}

Recharge was calculated in the WTF method using the formula

Groundwater recharge $=$ Geographic area $\times$ Specific yield

$$
\times \text { Rise in the water table. }
$$

The WTF method is used in this study because frequent and accurate water-level measurements are available in all observation wells of entire basin. 


\section{Estimation of groundwater recharge from RIF method}

The groundwater recharge from rainfall infiltration method can be obtained from the following relation

Groundwater recharge $=$ Geographic area $\times$ Normal rainfall

$$
\times \text { Infiltration factor. }
$$

\section{Estimation of per cent rainfall converted into groundwater recharge}

As per GEC-1997 norms, the rainfall recharge as computed by WTF method has been compared with that of RIF method, and finally, the rainfall recharge is assigned a value on the basis of set criteria so as to avoid unreasonably high or low estimates.

A quantity called percentage difference (PD) which is the difference between the rainfall recharge computed by the water table method $(A)$ and the recharge by the rainfall infiltration method $(B)$ and expressed as a percentage of the rainfall recharge by rainfall infiltration method is computed in Eq. 3:

Percentage difference $(P D)=[(A-B) / B] \times 100$

where ' $A$ ' is the rainfall recharge by WTF method and ' $B$ ' is the rainfall recharge by RIF method.

The set criteria (GEC 1997) to be adopted are as follows

(a) If $\mathrm{PD} \geq-20$ and $<+20 \%$, then the value of water table fluctuation method is adopted.

(b) If $\mathrm{PD} \leq-20 \%$, then the value of $0.8 \times$ rainfall infiltration factor method is adopted.

(c) If $\mathrm{PD} \geq+20 \%$, then the value of $1.2 \times$ rainfall infiltration factor method is adopted.

By following the above criteria, groundwater recharge is estimated.

\section{Results and discussion}

\section{Annual groundwater recharge in the basin}

To estimate the groundwater level rise in the basin, the premonsoon and post-monsoon groundwater levels at 42 locations covering entire basin are collected during the years 2013, 2014, 2015 and 2016. The difference of depth to water levels is estimated and is contoured using SURFER software (Fig. 4). The rise in the water table during the rainy season is used to estimate the recharge. Since there is very less pumping of groundwater for irrigation during monsoon period, the rise in water table is primarily due to the rainfall recharge. Areas between successive contours of groundwater level fluctuations are estimated by using the ArcGIS software.

To apply the WTF method, an estimation of the specific yield $\left(S_{\mathrm{y}}\right)$ at the depth of water table fluctuation is required. The specific yield $\left(S_{\mathrm{y}}\right)$ values of different formations are adopted from the values recommended by groundwater estimation committee (GEC 1997) based on local geology. As per local geology of study area, the recommended value of $3 \%$ is adopted for calculating the groundwater recharge (Table 1).

The total groundwater recharge by WTF method by applying the suitable specific yield to the basin is presented in Table 2.

The daily rainfall data of five mandals, namely Cheepurupally, Garividi, Nellimarla of Vizianagaram districts and Ranastalam and Laveru mandals of Srikakulam, are collected from Andhra Pradesh State Economics and Statistics department, Hyderabad. The monsoon rainfall is estimated for each mandal. The contour maps of monsoon rainfall by using SURFER software are shown in Fig. 5.

The infiltration factor value of $11 \%$ recommended by GEC based on local geology (Table 1) is taken.

Areas between successive contours of rainfall are estimated by using the ArcGIS 9.3 software. The total groundwater recharge by rainfall infiltration method by applying the infiltration factor to the basin is presented in Table 2. The per cent of rainfall converted into groundwater recharge for the years 2013, 2014, 2015 and 2016 is shown in Table 2.

\section{Influence of pre-monsoon groundwater levels over the rainfall recharge to groundwater}

Pre- and post-monsoon groundwater levels are observed in the study area for the years 2013, 2014 and 2015. Graphs are drawn between pre-monsoon groundwater levels and the difference of pre-monsoon and post-monsoon groundwater levels.

From Fig. 6, it can be observed that the positive and linear correlation $\left(R^{2}=0.68\right)$ is shown between pre-monsoon groundwater levels and the rise in groundwater levels. This means that the deeper the groundwater table, the more the recharge that has occurred. This may be happened due to good amount of average annual rainfall of $1051.5 \mathrm{~mm}$ that has occurred in the basin in the year 2013. Moreover, rainfall of 337-664 mm has occurred in the basin in the month of October in the span of eight continuous rainy days (Table 3 ). According to Parry et al. (2007), groundwater recharge 


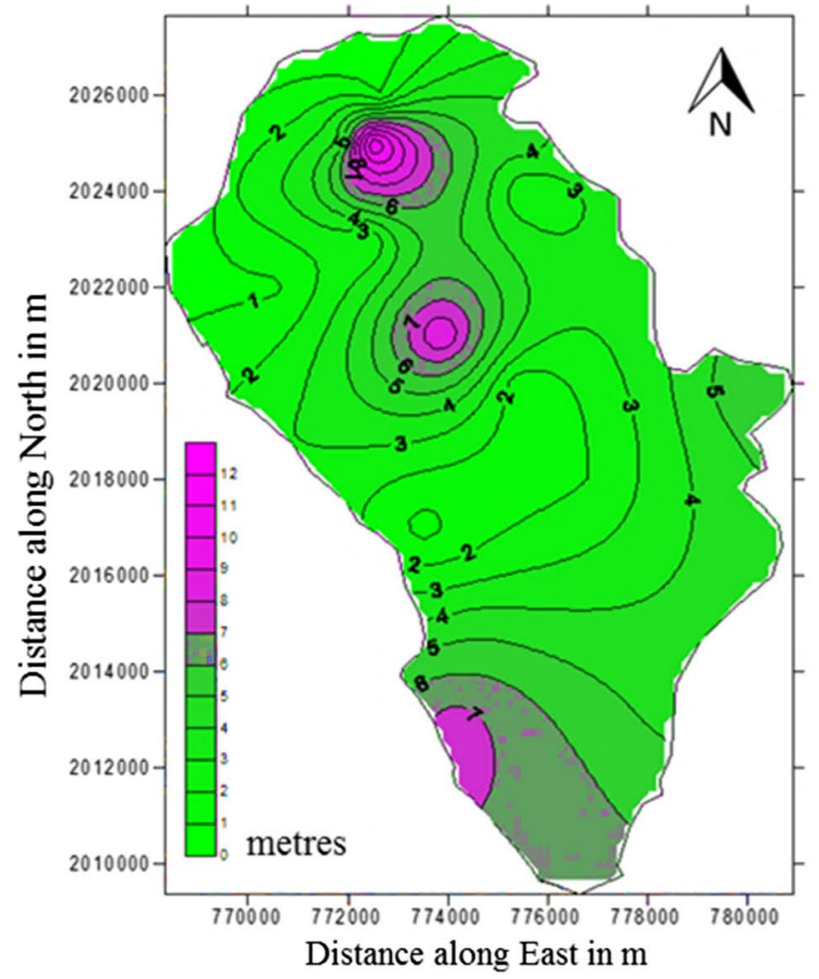

In the year 2013

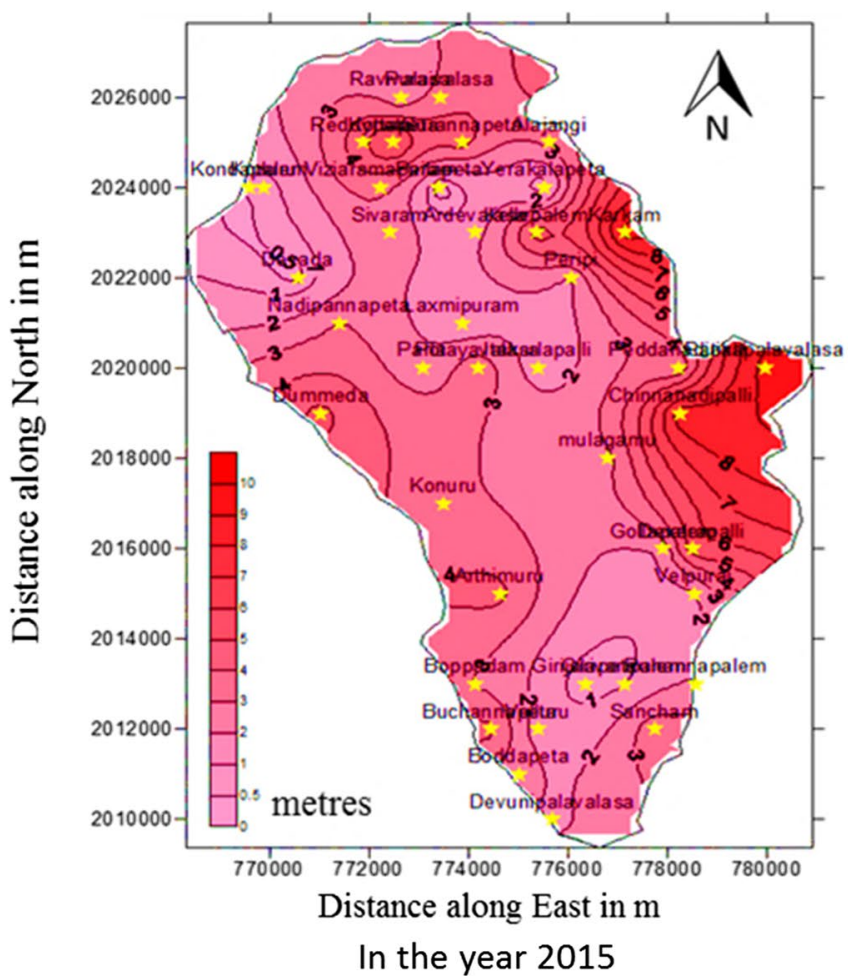



In the year 2014

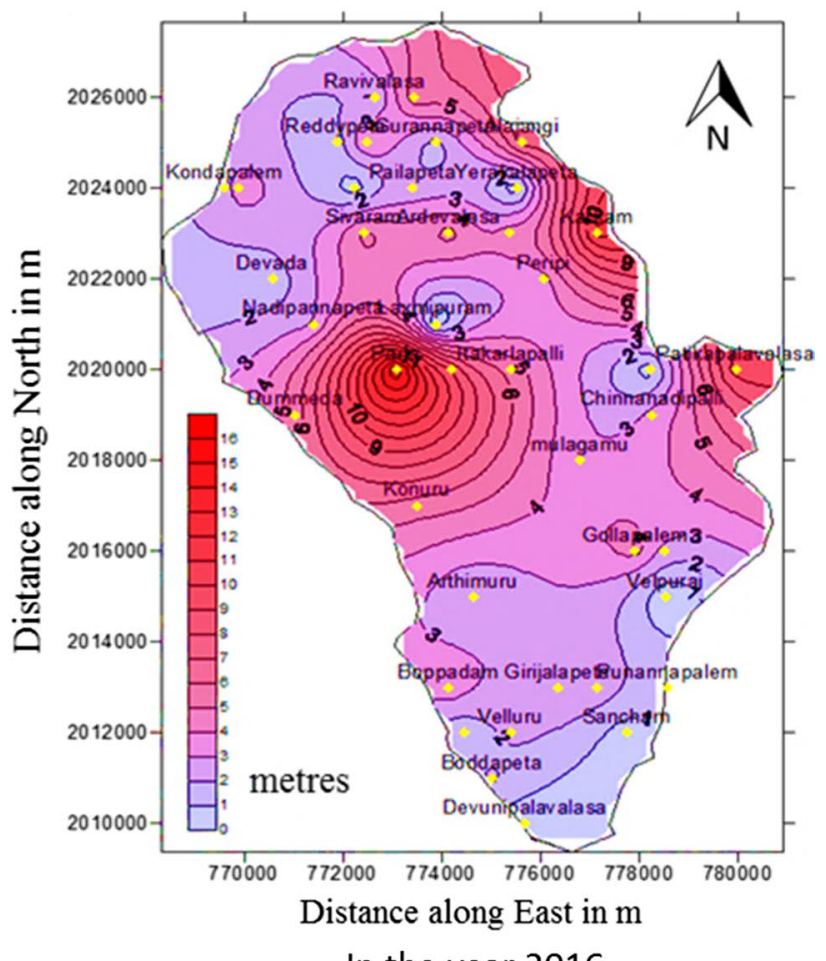

In the year 2016

Fig. 4 Contour maps of groundwater fluctuations of Kandivalasa river sub-basin in a.m.s.1 
Table 1 Norms for specific yield (GEC 1997)

\begin{tabular}{|c|c|c|c|c|c|c|c|}
\hline \multirow[t]{2}{*}{ S. no. } & \multirow[t]{2}{*}{ Rock type } & \multicolumn{3}{|c|}{ Specific yield as a fraction } & \multicolumn{3}{|c|}{ Rainfall infiltration factor as a fraction } \\
\hline & & Recommended & Maximum & Minimum & Recommended & Maximum & Minimum \\
\hline 1 & Karstified limestone & 0.08 & 0.15 & 0.05 & 0.06 & 0.07 & 0.05 \\
\hline 2 & Sandstone & 0.03 & 0.05 & 0.01 & 0.12 & 0.14 & 0.10 \\
\hline 3 & $\begin{array}{l}\text { Weathered granite, gneiss and } \\
\text { schist with low clay content }\end{array}$ & 0.03 & 0.04 & 0.02 & 0.11 & 0.12 & 0.10 \\
\hline 4 & Laterite & 0.025 & 0.03 & 0.02 & 0.07 & 0.08 & 0.06 \\
\hline 5 & Limestone & 0.02 & 0.03 & 0.01 & 0.06 & 0.07 & 0.05 \\
\hline 6 & $\begin{array}{l}\text { Weathered granite, gneiss and } \\
\text { schist with significant clay } \\
\text { content }\end{array}$ & 0.015 & 0.02 & 0.01 & 0.08 & 0.09 & 0.05 \\
\hline 7 & Quartzite & 0.015 & 0.02 & 0.01 & 0.06 & 0.07 & 0.05 \\
\hline 8 & Phyllites, shales & 0.015 & 0.02 & 0.01 & 0.04 & 0.05 & 0.03 \\
\hline 9 & Massive poorly fractured rock & 0.003 & 0.003 & 0.002 & 0.01 & 0.03 & 0.01 \\
\hline
\end{tabular}

Table 2 The per cent of rainfall converted into groundwater recharge for the years 2013, 2014, 2015 and 2016

\begin{tabular}{lllllll}
\hline Year & $\begin{array}{l}\text { Recharge in WTF } \\
\text { method }(A) \text { in } \\
\text { MCM }\end{array}$ & $\begin{array}{l}\text { Recharge in RIF } \\
\text { method }(B) \text { in } \\
\text { MCM }\end{array}$ & $\begin{array}{l}\text { Percentage difference } \\
(\mathrm{PD})=[(A-B) / B] \times 100 \\
\text { in \% }\end{array}$ & $\begin{array}{l}\text { Total groundwater } \\
\text { recharge in MCM }\end{array}$ & $\begin{array}{l}\text { Total Vol. } \\
\text { of rainfall in } \\
\text { MCM }\end{array}$ & $\begin{array}{l}\text { Per cent of rainfall converted } \\
\text { into groundwater recharge }\end{array}$ \\
\hline 2013 & 13.92 & 13.86 & 0.43 & 13.92 & 125.16 & 11.12 \\
2014 & 14.60 & 12.18 & 19.86 & 14.60 & 110.7 & 13.18 \\
2015 & 11.30 & 13.02 & -13.21 & 11.30 & 118.8 & 9.51 \\
2016 & 13.36 & 11.47 & 16.47 & 13.36 & 104.30 & 12.80 \\
\hline
\end{tabular}

may increase in areas where heavy precipitations are major sources of groundwater recharge.

Even though less rainfall has occurred in the year 2014, the more recharge has occurred than 2013 and 2015 with WTF method and positive correlation $\left(R^{2}=0.59\right)$ is observed from the graph (Fig. 7). This may be due to heavy rainfall of $303 \mathrm{~mm}$ in Cheepurupally, $315 \mathrm{~mm}$ in Garividi, $390 \mathrm{~mm}$ in Nellimarla recorded in three continuous rainy days during Hudhud Cyclone (12-14 October 2014) in the basin (Table 3).

The application of stable isotope tracers and soil-moisture balance models in tropical Africa has also highlighted the importance of heavy rainfall events ( $>10 \mathrm{~mm}$ per day) in determining the magnitude of rainfall-fed recharge. Eilers et al. (2007) also showed that the sum of heavy rainfall events exceeding a threshold of $10 \mathrm{~mm}$ per day is better related to the recharge flux than the sum of all daily events. Table 3 shows heavy rainfall with eight successive rainy days in the year of 2013 and three successive rainy days in the year of 2014 and twelve successive rainy days in the year of 2016 .
From the graph in Fig. 8, there is less linear correlation $\left(R^{2}=0.33\right)$ between pre-monsoon groundwater levels and groundwater level rise in the year 2015 and also there is no much groundwater level rise. The groundwater recharge is also less in WTF method in the year 2015 when compared to other three years (Table 2). Since there is no continuous rainfall of more than $10 \mathrm{~mm}$ per day for over many days in the year 2015, it could be the reason for less groundwater recharge (11.3 MCM) when compared to the other three years by WTF method (Table 2).

From Fig. 9 it can be observed that in the year 2016, the positive and linear correlation $\left(R^{2}=0.61\right)$ is shown between pre-monsoon groundwater levels and the rise in groundwater levels. This means that in the year 2016 also as in the case of 2013 and 2014, the deeper the groundwater levels more the recharge that has occurred. It can be observed from Table 3 that even though less rainfall has occurred in the year 2016 similar to the year 2014, the more recharge has occurred in the basin. This may be due to fact that heavy rainfall of $256 \mathrm{~mm}$ in Cheepurupally, $360.2 \mathrm{~mm}$ in Garividi, $344.9 \mathrm{~mm}$ in Nellimarla has occurred in the basin during in the months 


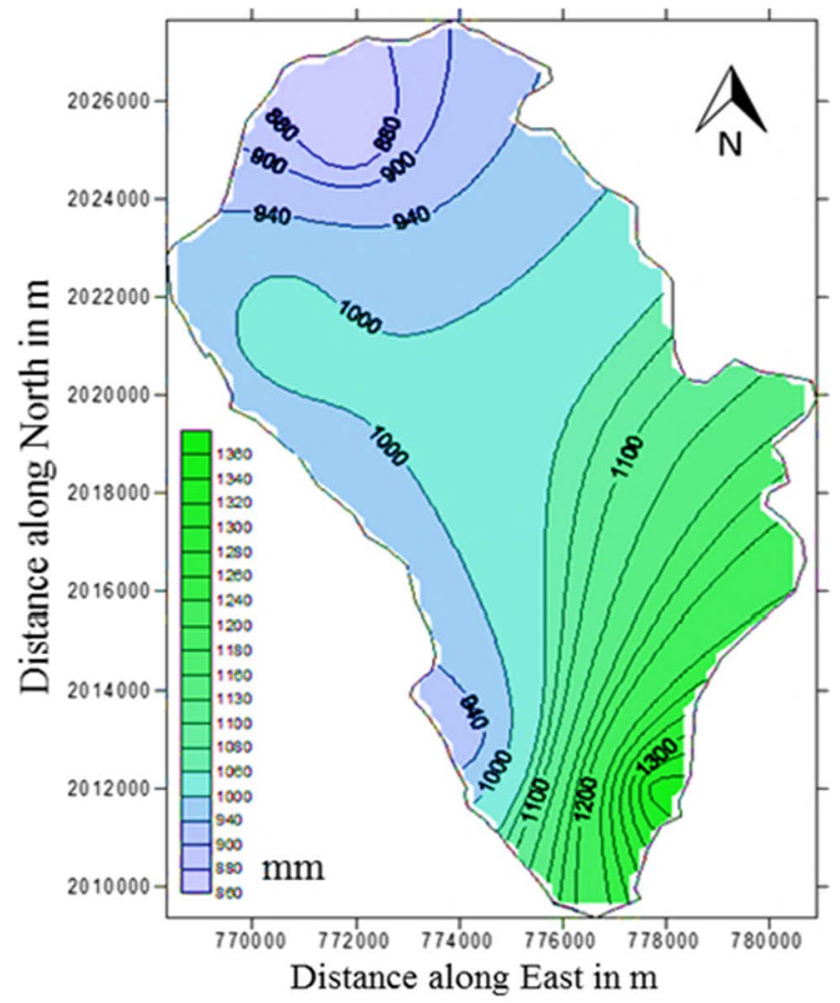

In the year 2013

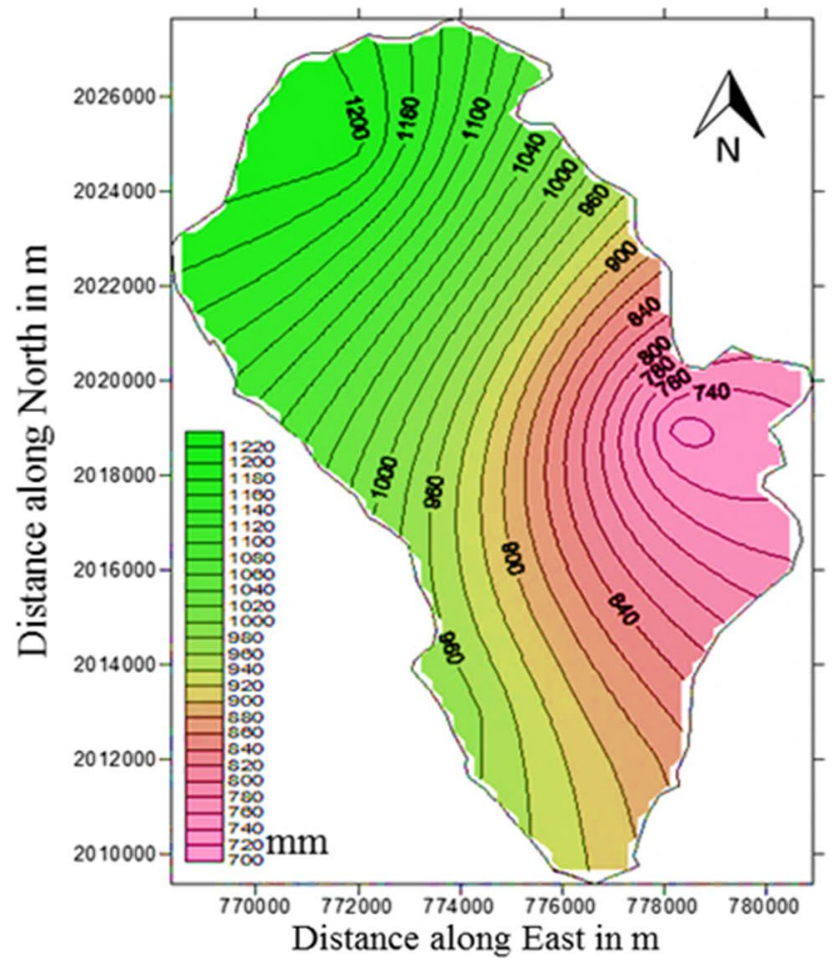

In the year 2015

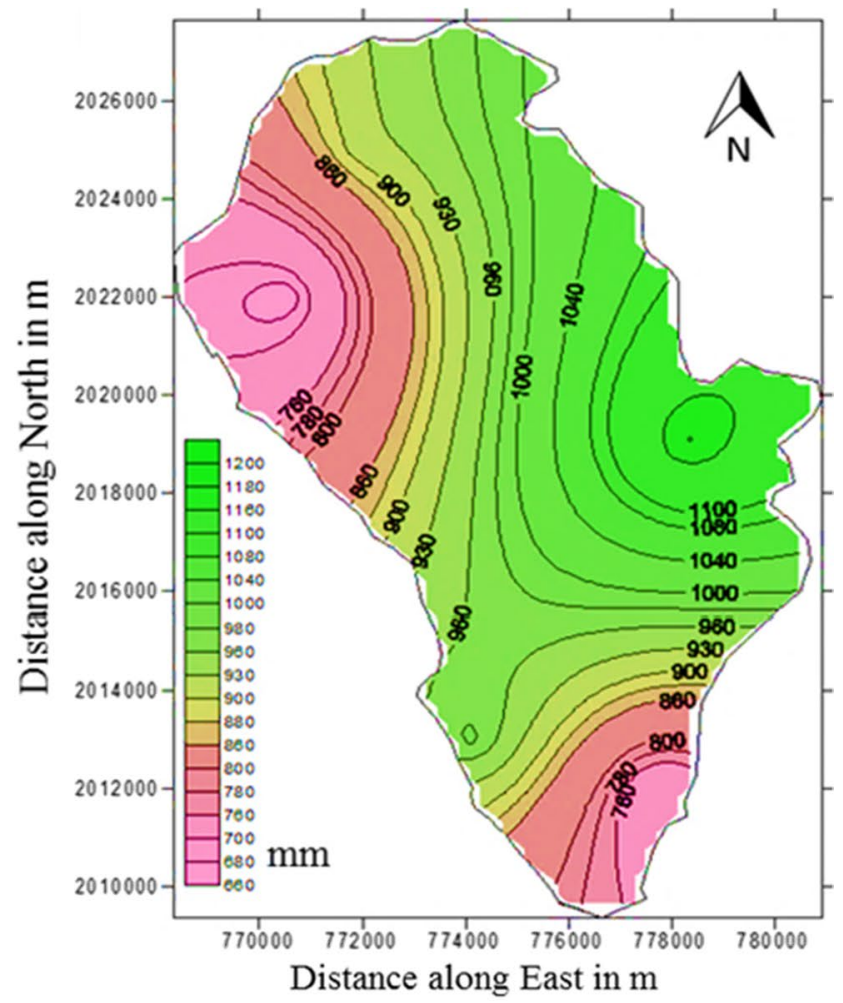

In the year 2014

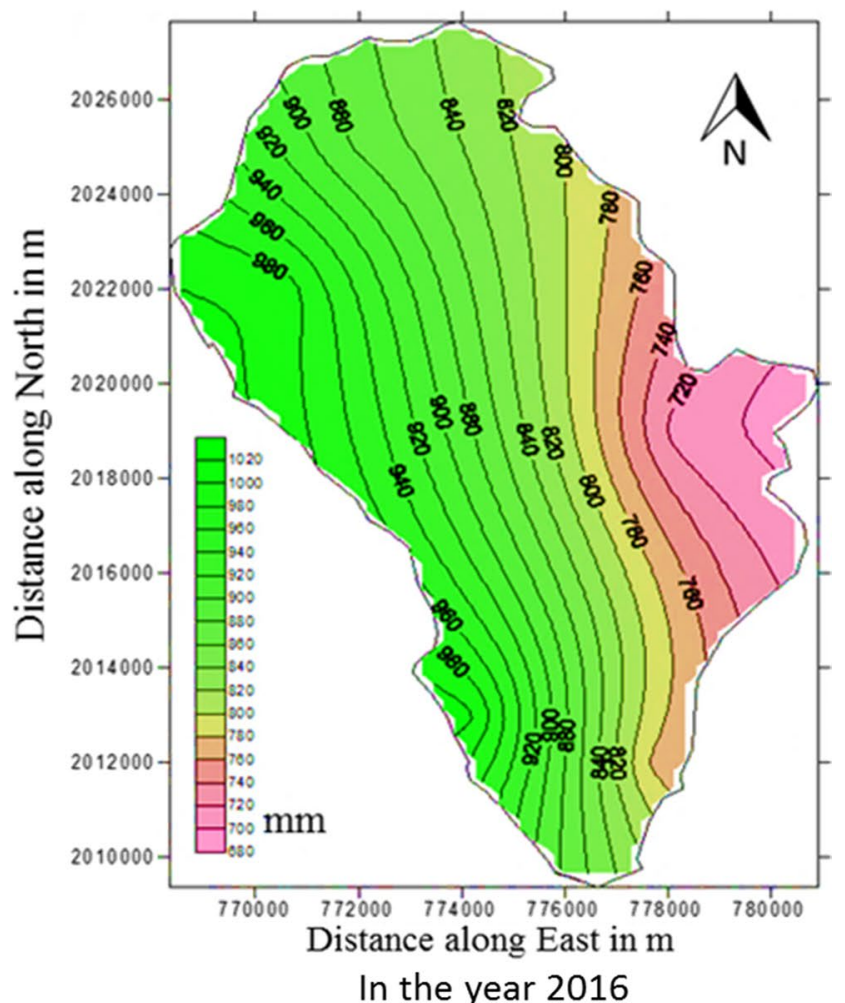

In the year 2016

Fig. 5 Contours of monsoon rainfall of Kandivalasa river sub-basin 


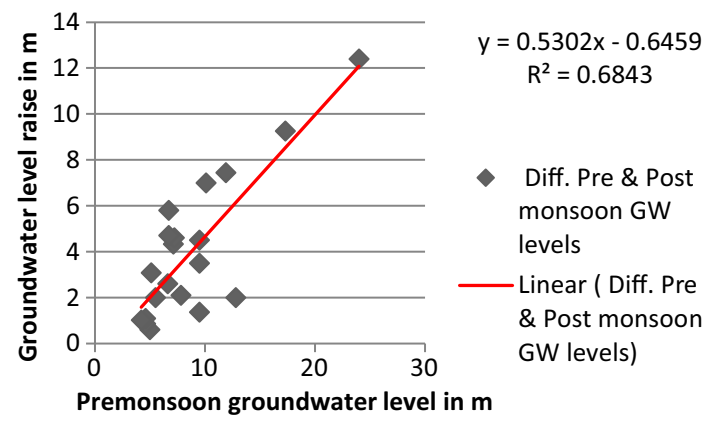

Fig. 6 Relation between pre-monsoon groundwater levels and the difference of pre- and post-groundwater levels in $\mathrm{m}$ of 2013



Fig. 7 Relation between pre-monsoon groundwater levels and the difference of pre- and post-groundwater levels in m of 2014



Fig. 8 Relation between pre-monsoon groundwater levels and the difference of pre- and post-monsoon groundwater levels in $\mathrm{m}$ of 2015

of September-October in a span of twelve continuous rainy days (Table 3 ).

From Figs. 6, 7, 8 and 9, it can be observed that the amount of recharge is directly proportional to the pre-monsoon groundwater levels (Venkateswara Rao et al. 2009). It means that the deeper the pre-monsoon level the more the recharge that has occurred. It is also observed that the

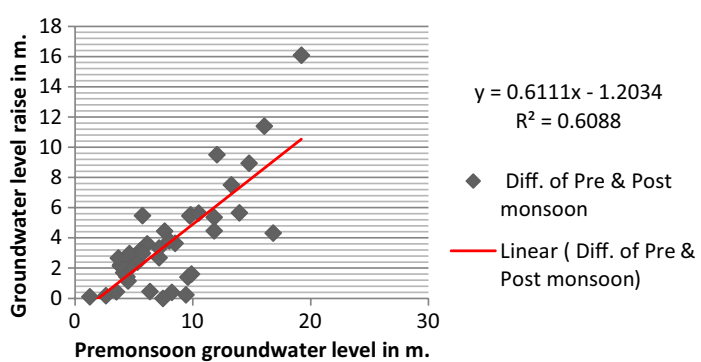

Fig. 9 Relation between pre-monsoon groundwater levels and the difference of pre- and post-monsoon groundwater levels in $\mathrm{m}$ in the year 2016

groundwater recharge is influenced by heavy rainfall of more than $300 \mathrm{~mm}$ with prolonged time. This heavy rainfall for a particular year has led to the groundwater levels rise. Hence, even though less rainfall has occurred in the year 2014, the more recharge has occurred than the years 2013, 2015 and 2016 with WTF method. Hence, groundwater recharge is increased due to the events of heavy rainfall with prolonged time during study period (Table 3).

\section{Conclusions}

Groundwater recharge is estimated from the Kandivalasa river sub-basin at east coast of India covered with khondalitic suite of rocks by using a methodology developed by Groundwater Estimation Committee of Central Ground Water Board of India. The per cent rainfall converting to the groundwater recharge in the basin is $11.12,13.18,9.51$ and $12.80 \%$ for the years 2013, 2014, 2015 and 2016, respectively. Groundwater recharge studies are indicating that the amount of groundwater recharge is directly proportional to the pre-monsoon groundwater levels in the basin. The study has also revealed that the deeper the pre-monsoon groundwater level, the more the recharge that has occurred in the basin. Moreover, it has been observed that the heavy rainfall events of more than $300 \mathrm{~mm}$ with prolonged time lead to the rise of the groundwater levels thereby increasing the groundwater recharge. This means that, irrespective of the total amount of annual precipitation in the basin, continuous high precipitation events exceeding a rainfall of $300 \mathrm{~mm}$ in any particular year have led to the rise of groundwater levels in that year. Hence, it is found that heavy precipitations are 
Table 3 Heavy rainfall in ' $m$ ' with prolonged time in the years 2013, 2014 and 2016

\begin{tabular}{lllll}
\hline S. No. & $\begin{array}{l}\text { Name of the } \\
\text { rain gauge } \\
\text { station }\end{array}$ & $\begin{array}{l}\text { Rainfall of 8 successive } \\
\text { days in October 2013 }\end{array}$ & $\begin{array}{l}\text { Rainfall of 3 successive } \\
\text { days in October 2014 }\end{array}$ & $\begin{array}{l}\text { Rainfall of 12 successive } \\
\text { days in September-October } \\
2016\end{array}$ \\
\hline 1 & Cheepurupally & 380.2 & 303 & 256 \\
2 & Garividi & 336.7 & 315 & 360.2 \\
3 & Nellimarla & 382.0 & 390 & 344.9 \\
4 & Ranastalam & 664.3 & 203.3 & 159.3 \\
5 & Laveru & 554.6 & 160.7 & 150.2 \\
\hline
\end{tabular}

major sources for increasing the groundwater recharge in the study area.

Acknowledgements Authors are thankful to the Science and Engineering Research Board (SERB), Department of Science and Technology, Government of India, for funding the research project.

Open Access This article is distributed under the terms of the Creative Commons Attribution 4.0 International License (http://creativeco mmons.org/licenses/by/4.0/), which permits unrestricted use, distribution, and reproduction in any medium, provided you give appropriate credit to the original author(s) and the source, provide a link to the Creative Commons license, and indicate if changes were made.

\section{References}

Bhuiyan C, Singh PR, Flugel WA (2009) Modelling of groundwater recharge-potential in the hard-rock Aravalli terrain, India: a GIS approach. Environ Earth Sci 59:929-938

Cooper DJ, Wolf EC, Ronayne MJ, Roche JW (2015) Effects of groundwater pumping on the sustainability of a mountain wetland complex, Yosemite National Park, California. J Hydrol Reg Stud 3:87-105

Crosbie RS, Binning P, Kalma JD (2005) A time series approach to inferring groundwater recharge using the water table fluctuation method. Water Resour Res 41:W01008

Delin GN, Healy RW, Lorenz DL, Nimmo JR (2007) Comparison of local to regional scale estimates of groundwater recharge in Minnesota, USA. J Hydrol 334:231-249

Eilers VHM, Carter RC, Rushton KR (2007) A single layer soil water balance model for estimating deep drainage (potential recharge): an application to cropped land in semi-arid north-east Nigeria. Geoderma 140:119-131

GEC (Groundwater Estimation Committee) (1997) Groundwater resource estimation methodology. Report of Ministry of Water Resources, New Delhi, India

Healy RW (2010) Estimating groundwater recharge. Cambridge University Press, Cambridge

Healy RW, Cook PG (2002) Using groundwater levels to estimate recharge. Hydrogeol J 10:91-109

Jan CD, Chen TH, Lo WC (2007) Effect of rainfall intensity and distribution on groundwater level fluctuations. J Hydrol 332:348-360

Jasrotia AS, Kumar A (2014) Estimation of replenishable groundwater resources and their status of utilization in Jammu Himalaya, J\&K, India. Eur Water 48:17-27

Kumar GNP, Srinivas P (2012) Evaluation of groundwater resources and estimation of stage of groundwater development in a basin-a case study. Irrig Drain 61:129-139

Ngounou NB, Jacques M, Reynauld JS (2007) Groundwater recharge from rainfall in the southern Border of Lake Chad in Cameroon. World Appl Sci J 2:125-131
Nichols DS, Verry ES (2001) Stream flow and groundwater recharge from small forested watersheds in north central Minnesota. J Hydrol 245:89-103

Owor M, Taylor RG, Tindimugaya C, Mwesigwa D (2009) Rainfall intensity and groundwater recharge: empirical evidence from the Upper Nile Basin. Environ Res Lett 4:1-6

Parry M, Canziani O, Palutikof J, van der LP, Hanson C (2007) Climate change: impacts, adaptation and vulnerability. Cambridge University Press, Cambridge

Sethi RR, Kumar A, Sharma SP (2009) Quantification of groundwater recharge in a hard rock terrain of Orissa: a case study. Water Sci Technol 60:1319-1326

Shah T (2005) Groundwater and human development: challenges and opportunities in livelihoods and environment. Water Sci Technol 51:27-37

Siva Prasad Y, Venkateswara Rao B (2018) Groundwater depletion and groundwater balance studies of Kandivalasa river sub basin, Vizianagaram district, Andhra Pradesh, India. Groundw Sustain Dev 6:71-78

Sophocleous M (1991) Combining the soil water balance and water level fluctuation methods to estimate natural groundwater recharge: practical aspects. J Hydrol 124:229-241

Thomas T, Jaiswal RK, Ravi G, Surjeet S (2009) Development of a rainfall-recharge relationship for a fractured basaltic aquifer in Central India. Water Resour Manag 23:3101-3119

Varni M, Comas R, Weinzettel P, Dietrich S (2013) Application of the water table fluctuation method to characterize groundwater recharge in the Pampa plain, Argentina. Hydrol Sci J 58:1445-1455

Venkateswara Rao B, Briz-Kishore BH (1991) A methodology for locating potential aquifer in a typical semi-arid region of India using resistivity and hydrogeological parameters. J Geo-Explor 27:55-64

Venkateswara Rao B, Ramadurgaiah D (2002) Comparative study of resistivity soundings and lithologs in a khondalitic terrain in an area around Vizianagaram, A.P., India. In: Proceedings of international conference on hydrology and watershed management, vol 1. JNT University, Hyderabad, pp 132-143

Venkateswara Rao B, Varalakshmi V, Rajesh N, Pavan Kumar K, Satyanarayana B (2007) Estimation of groundwater recharge for the upper Musi basin using water table fluctuation method by GIS applications. J Appl Hydrol 21:91-105

Venkateswara Rao B, Varalakshmi V, Vijayasarada ST (2009) Groundwater recharge in hard rock areas of Musi basin. J Appl Hydrol 22:102-117

Wu J, Zhang R, Yang J (1996) Analysis of rainfall-recharge relationships. J Hydrol 177(1):143-160

Zomlot Z, Verbeiren B, Huysmans M, Batelaana O (2015) Spatial distribution of groundwater recharge and base flow: assessment of controlling factors. J Hydrol Reg Stud 4:349-368

Publisher's Note Springer Nature remains neutral with regard to jurisdictional claims in published maps and institutional affiliations.

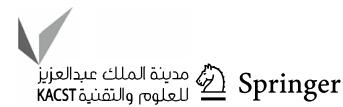

